\title{
Review
}

\section{Fugitive Rousseau: Slavery, primitivism and political freedom}

\author{
Jimmy Casas Klausen \\ Fordham University Press, New York, 2014, xvii+333pp., \$65.00/£41.00 \\ ISBN: 978-0823257294 \\ Contemporary Political Theory (2015) 14, e220-e223. doi:10.1057/cpt.2014.27; \\ published online 28 October 2014
}

Jean-Jacques Rousseau's writings abound with references to slavery. There were few things he appears to have enjoyed more than chiding his contemporaries for failing to realize that the freedom to which they laid claim was illusory and that they were really little better than slaves. Yet, Rousseau is usually read as having largely neglected the race-based slavery of his own day, and thus might seem to have very little to offer those concerned with postcolonial problems. In Fugitive Rousseau, Jimmy Casas Klausen challenges this view by advancing an ambitious and strikingly original interpretation of Rousseau's ideas on slavery and political freedom. Klausen situates Rousseau's writings in the context of European colonialism and empire, and aims to reconstruct an account of 'fugitive freedom' from Rousseau's various remarks on political resistance. The title, then, which alludes to Wolin's (1994) notion of 'fugitive democracy', refers not to Rousseau himself, but rather to the collective fugitivity of 'marooning body politics in the making' (p. 28).

Fugitive Rousseau is set out in two parts: the first explores the problem of slavery in Rousseau's thought, while the second evaluates Rousseau's different projects for achieving political freedom. The first main chapter addresses a question rarely asked by Rousseau scholars: If slavery is nothing other than mere force, then how does Rousseau explain why slaves do not rebel whenever the opportunity arises? Klausen provides a detailed and careful analysis of the opening chapters of the Social Contract, before turning to the Discourse on the Origins of Inequality to reveal how, by the coincidence of chance circumstances, institutionalized docility gradually becomes established. This is one of the most illuminating parts of the book, and Klausen convincingly shows that all forms of slavery presuppose the closing off of land that arises with the advent of private property.

Where the first chapter focuses on the structural features of slavery, the second explores slavery as a moral relation. Here Klausen attends closely to the place of Stoic ideas in Rousseau's account of freedom and slavery, a theme that remains prominent throughout much of the book. Indeed, Klausen later presents fugitive 
self-liberation in direct opposition to Stoic self-emancipation (p. 154), these being two competing models of freedom between which Rousseau was divided at different points in his auvre. The chapter also addresses a problem, central to Klausen's overall argument, concerning the relationship between Rousseau's 'primitivism' the simple way of life enjoyed by savage people in nascent society - and political freedom. Klausen argues that the savage is the exemplary member of all free peoples (p. 99; see also p. 190), but this stretches the meaning of the passage from the Discourse on the Origins of Inequality that he cites in support of his claim. While the independence of the savage certainly shares something in common with political liberty - absence from dependence on the will of others - Rousseau (1964) elsewhere stressed that liberty and independence are not one and the same, and, on one occasion at least, even described them as mutually exclusive (pp. 841-842). Where the savage is independent, the idea at the heart of Rousseau's account of political liberty is dependence on the law, as opposed to dependence on the will of others. This is a model of freedom that Rousseau (1964) thought best exemplified by republican Rome, as he made clear in the dedication to the Discourse (p. 113), but which is largely neglected in Klausen's analysis of political liberty.

The reason why the last point is important concerns the transition to the second part of the book, where Klausen focuses on political freedom. Before presenting his reading of fugitive freedom, Klausen assesses whether either Émile's education or a Rousseauian autarkic republic could succeed in securing political freedom. There is much to admire in the analysis of Émile, especially the discussion of the place of travel in the development of Émile's freedom and the criticisms of those who have read too much cosmopolitanism into Rousseau. Klausen instead argues that the tutor instils in Émile 'a countercosmopolitanism as a negative ideal' (p. 131). Ultimately Klausen arrives at the familiar conclusion that if Émile's education aims at autonomy then it is a failure, since it has been secretly predetermined by his tutor (pp. 143-147). However, while Klausen's criticisms of the freedom to which Émile's education is directed are plausible, I remain less convinced by what he has to say about Rousseau's autarkic republics, for reasons that stem from how he reads Rousseau's primitivism and its relation to political liberty.

When discussing primitivism, Klausen argues that Rousseau is torn between two rival Hellenistic approaches: a Stoic approach that sharply distinguishes between primitive simplicity and true virtue, and an Epicurean approach where the difference between primitive and civilized beings is one of degree, not of kind (p. 189). Klausen's phrasing in the introduction is particularly revealing: these contrasting Hellenistic arguments, 'when taking to their logical extremes, pull Rousseau's writings in different, sometimes irreconcilable directions' (p. 26). Even if it is true that these arguments are irreconcilable when taken to their logical extreme, it is unclear that the conflict between these two understandings of primitivism pervades Rousseau's writings to the degree Klausen suggests. There are certainly many Stoic and Epicurean themes at play in the Discourse on the Origins of Inequality 
(see Brooke, 2010), as there are Stoic themes in Émile, but it is less evident that the Stoic/Epicurean dichotomy proves quite so helpful for understanding Rousseau's more overtly political writings, at least to the extent that it would have to for many of Klausen's criticisms to hold. For example, Klausen attributes to Rousseau a 'relativist conception of the general will', which apparently owes something to his Epicurean rejection of a cosmopolitan order. But this strikes me as an instance where reading Rousseau's ideas through the Stoic/Epicurean dichotomy does a disservice to both his originality and the array of possible (ancient) sources upon which he drew, attention to which could easily deflect the charge of relativism (for example, see Williams, 2005).

In the final chapter, Klausen elucidates his own reading of fugitive freedom in Rousseau. This is, admittedly, a speculative and even heterodox interpretation, which proceeds by foregrounding issues of resistance and rebellion that Rousseau discussed only briefly and unsystematically. Klausen's approach, then, involves asking what Rousseau might have thought if he had been preoccupied by a different set of questions to those that actually concerned him. What emerges from this approach is an imaginative reconstruction of Rousseau's ideas of insurgent self-determination, which probably takes enough from Rousseau to merit the description Rousseauian, even if, at times (as elsewhere in the book), the influence of Michel Foucault is perhaps stronger, such as when Klausen finds in Rousseau the possibility of 'a Foucaultian understanding of resistance' (p. 241). In an afterword, the contemporary resonance of Klausen's argument becomes clearer and more prominent, as he assesses the merits of his theory by comparing fugitive freedom with ideas central to recent Italian and French radical political thought.

Klausen's interpretation of Rousseau is a challenging one, and some of his arguments are likely to meet with resistance from Rousseau scholars. But this is probably to be welcomed given the nature of the book, which addresses many oftneglected themes and contains some illuminating discussions of topics, like slavery, that merit greater attention from Rousseau scholars. Indeed, while Klausen is principally engaged in interpreting Rousseau throughout most of the book, he is explicit that his purpose is not simply to offer a sympathetic interpretation or exegesis. When Klausen claims that Rousseau's arguments fail, he is 'less interested in attributing this to Rousseau and implicitly suggesting that the auteur has failed his readers' (p. 25). Who are the readers in question? Klausen does not say, but it seems to me that he has in mind those who seek to develop a far more radical form of politics than that which Rousseau would ever have championed. Fugitive Rousseau is as much a book for them as it is for Rousseau scholars.

\section{References}

Brooke, C. (2010) Rousseau's Second Discourse: Between epicureanism and stoicism. In: C. McDonald and S. Hoffman (eds.) Rousseau and Freedom. Cambridge, UK: Cambridge University Press, pp. 44-57.

e222 (C) 2015 Macmillan Publishers Ltd. 1470-8914 Contemporary Political Theory Vol. 14, 2, e220-e223 
Rousseau, J.J. (1964) Euvres complètes de Jean-Jacques Rousseau, vol. 3: Du contrat social; Écrits politiques. B. Gagnebin and M. Raymond (eds.) Paris, France: Gallimard.

Williams, D.L. (2005) Justice and the general will: Affirming Rousseau's ancient orientation. Journal of the History of Ideas 66(3): 383-411.

Wolin, S.S. (1994) Fugitive democracy. Constellations 1(1): 11-25.

Robin Douglass

Department of Political Economy, King's College London, London WC2R 2LS, UK robin.douglass@kcl.ac.uk 